Peer-Reviewed Article

\author{
OOJED \\ International Journal of \\ Multidisciplinary Perspectives in Higher Education \\ Volume 3, Issue 1 (2018) \\ https://www.ojed.org/jimphe \\ Print ISSN 2474-2546 \\ Online ISSN 2474-2554) \\ doi: 10.5281/zenodo.2525829
}

\title{
Shifting Teacher Cultural Awareness and Teaching through Study Abroad Experiences
}

\author{
Lydia Kyei-Blankson \\ Illinois State University, United States \\ Mohamed Nur-Awaleh \\ Illinois State University, United States
}

\begin{abstract}
Preservice teacher study abroad experiences and its influence on cultural awareness and teaching is explored in this paper. Participants in this study include preservice teachers from a large teacher education program. Teacher reflections and one-on-one semi-structured interview data were gathered, transcribed, coded, and analyzed for themes. The preservice teacher responses show generally an overall positive study abroad experience. Through their study abroad experiences, the preservice teachers learned about a different culture, different customs and a different language. They also learned about how a different country's school system works. One of the implications of this study is that we recommend that colleges' of education as well as other colleges to develop a robust funding mechanism that include scholarships that will defray the cost of studying abroad, especially for underrepresented students. The finding and results from this study can be used as way to internationalize campuses. Indeed, preservice students in our data noted that they enjoyed their experience and gained cultural competence skills that will enhance their preservice teaching experiences.
\end{abstract}

Keywords: Study Abroad, Teacher Education, Cultural Awareness, Culturally Responsive Teaching 
As the world continues to become smaller and more interconnected, participation in the competitive global market that arises as a result, demands individuals who are competent and globally aware citizens. Participation in study abroad programs is one of the ways to increase the number of engaged global citizens. Morais and Ogden (2011) defined global citizenship as "a multidimensional construct that hinges on the interrelated dimensions of social responsibility, global competence, and global civic engagement" (p. 5) and went further to elaborate "it is the presence of each of these dimensions that leads to global citizenship" (p. 5). Study abroad may offer learning experiences and other benefits that help make individuals global citizens.

While study abroad programs have expanded in the United States as a result of studies calling for "global competence" to be a priority for academic areas and disciplines (Lincoln Commission, 2006; Mullens \& Cuper, 2012), participation in study abroad programs is nowhere near the goal of at least one million U.S. undergraduate students per year as mentioned by Senator Dick Durbin in the 2006 Lincoln Commission and The Future of Study Abroad report. In the Executive Summary of a recent Open Doors report on the state of study abroad in the United States, Morris (2017) notes that:

Although the total number [of students studying abroad] is at an all-time high, it is still the case that only about 10 percent of all U.S. undergraduate students (including community college students) will study abroad by the time they graduate. The fact that 90 percent of all American undergraduate students enrolled in U.S. higher education are graduating without an international experience means that there is still a long way to go. For students pursuing a Bachelor's degree, approximately $15.5 \%$ studied abroad before graduating (See IIE Open Doors report, para 14)

A challenge facing study abroad is with the diversity composition of the study abroad population. The demographics or background characteristics of study abroad participants have remained largely the same and homogenous with most students being white females from the humanities and/or social sciences (Twombly, Salisbury, Tumanut, \& Klute, 2012). Another issue associated with study abroad is the nature and purpose of the programs. For instance, Twombly, Salisbury, and Turnanut (2012) noted that "rarely do faculty, policymakers, study abroad directors, or advocates question study abroad, its purposes, or its benefits" (p. 95). Furthermore, some authors have raised questions about the new-liberal aspects of study abroad programs, how these programs are structured, who benefits from it, and who is left behind. For example, Giroux (2002) indicated that:

As society is defined through the culture and values of neoliberalism, the relationship between a critical education, public morality, and civic responsibility as conditions for creating thoughtful and engaged citizens 
are sacrificed all too willingly to the interest of financial capital and the logic of profit-making (p. 427).

In the face of these challenges, study abroad is still promoted because it leads to beneficial outcomes. In their 2010 scholarship on the history of study abroad in the United States, Hoffa and DePaul advanced four main arguments for study abroad: "the curricular argument, the cross-cultural argument, the career enhancement argument, and the development argument" (p.8). Essentially, colleges and universities in the United States offer different types of study abroad programs ranging from faculty lead short term programs to year-long programs and participants who study abroad are involved in learning that occurs beyond their classroom walls; they learn about other cultures, develop essential workplace skills, develop intellectually, socially, and emotionally, and do all these things while pursuing their academic degrees.

As such, in the field of teaching where demographic challenges and cultural disparities exist between teachers and their students, participation in study programs could be essential. Through the study abroad experience, teachers will have the opportunity to live and interact in communities that are different from their own, and yet similar to those their students'. As such, participation in study abroad programs could help prepare teachers to teach and work more effectively with their ethnically, culturally, and linguistically diverse students and families (Sleeter, 2001).

Researchers such as Ladson-Billings (1994; 1995) and Gay (2010) discuss the need for training teachers in culturally responsive and relevant pedagogy. According to Ladson-Billings, the use of culturally responsive and relevant pedagogy involves teacher recognition and implementation of teaching methods, practices, strategies, and references that match the diverse cultural backgrounds of their students and families. Such teaching can empower students "intellectually, socially, emotionally and politically" (Ladson-Billings, 1994, p. 20) and thereby will enhance learning. Again, given the potential outcomes of study abroad programs, teacher participation in study abroad could help them understand better and adopt culturally responsive practices.

It is, therefore, recommended that teachers be encouraged to participate in study abroad programs. Also, it is important that study abroad for teachers be examined to ensure that indeed, the programs do have the intended effects. Phillion, Malewski, Sharma, \& Wang (2009) pointed out that "study abroad in teacher education remains under-researched, under-theorized and underevaluated." (p. 325). In addition, currently, there are only but a few studies that focus on examining the ways in which teacher study abroad experiences lead to the necessary shifts in their teaching. There is a need to understand how teachers benefit from the study abroad experience, and more especially, how their experiences translate into their teaching and in a way that meets the needs of their students who are from diverse backgrounds (Quezada \& Alfaro, 2007).

The current study analyzed the study abroad experiences of preservice teachers from a large teacher education program at a university located in 
Midwestern United States. This area occupies the northern central part of the United States. In this study, how the study abroad experiences influenced the preservice teacher plans for teaching and working with diverse student populations and families are explored. The college of education (COE) in which the preservice teachers are enrolled provides study abroad opportunities to many international locations including England, Ireland, Costa Rica, Spain, Brazil, Taiwan, Mexico, and Japan, and the study abroad programs last anywhere from four weeks to four months. As part of the study abroad experience, the preservice teachers get to live on international university campuses or with host families and are involved in observing and/or teaching in PreK-12 classrooms comprising culturally and linguistically diverse students.

The research questions this study seeks to address include:

1. What are the experiences of the preservice teachers who participate in the COE study abroad programs?

2. In what ways do preservice teachers believe their study abroad experiences have influenced their own teaching practices?

3. Given their study abroad experience, how do the preservice teachers plan, in the future, to work with other students and families from culturally and linguistically diverse backgrounds in the United States?

The findings from this study provide insights into the effects of the study abroad experience on preservice teachers' development, and specifically on how their experiences have informed their plans for working with diverse populations. In general, the results of this study add on important information to the existing literature concerning the effects of study abroad on teacher education.

\section{Methodology}

A qualitative research design was used in this study as this design allows for an in-depth exploration of participants' experiences (Creswell \& Poth, 2016; Patton, 2015). Approval to conduct the study was obtained from the Institutional Review Board (IRB) prior to data collection.

Participants in this study were six COE elementary and secondary education preservice teachers (five women and one man; four Caucasian, one Hispanic, and one of Arabic heritage) from a large Midwestern university who participated in a four-week long summer study abroad program to Japan in the summer of 2017. None of the preservice teachers had international travel experience or experience with the Japanese language/culture. The summer study abroad experience included home-stay with Japanese family, taking courses and interacting with other preservice teachers at a Japanese university, PreK-12 school visits and observations, visits to cultural sites such as museums and temples, and participation in cultural events and activities such as festivals and tea ceremonies. Individually, the preservice teachers earned from two to six credit hours towards their academic degrees while participating in the study abroad experience.

In this study, the preservice teachers were asked to sit for one-on-one 45- 
minutes to one-hour long semi-structured interviews after returning from their studying abroad trip. The interview included questions such as what were your expectations of your study abroad program? What did you hope to learn? What did you learn during your participation in the study abroad program? In what ways did your experience influence your plans for teaching? How has your understanding of working with ethnically, culturally, and linguistically diverse students and families changed after your participation in the study abroad program? The preservice teachers were also asked to share reflection notes they had made in relation to their experience in the program. The data gathered from the interviews and reflection notes were analyzed to explore the preservice teacher experiences, and how participation in the study abroad program had influenced their plans for teaching and working with students and families from diverse backgrounds. The data were coded using open coding and then analyzed for themes as recommended by Patton (2015). The findings of the study were member checked and peer-reviewed to ensure accuracy and trustworthiness.

\section{Researcher Positionality and Reflexivity}

As researchers, it is always important that we reveal who we are and how we are connected to our study (Merriam 2009). Indeed, Merriam (2009) indicated that qualitative research, "is not conducted so that the laws of human behavior can be isolated. Rather, researchers seek to describe and explain the worlds as those in the world experience it" (p. 220).

One of the researchers was the COE faculty coordinator for the study abroad program to Japan. She had experience traveling with preservice teachers to their study abroad location, and had participated in some of the cultural events and activities included in the program. She had also spent time observing in the elementary, middle, and high schools at the international location. The study abroad coordinator has also had the experience of living and studying in Japan as an international student for three years. In addition, during the course of her studies, she had the opportunity to work and interact with students from diverse backgrounds. Given this experience, the coordinator could be considered an insider where the preservice teachers were concerned as she could relate to their experience. However, because of her faculty status and as the researcher involved in collecting and analyzing the data, the coordinator could also be considered an outsider from the preservice teachers' perspective. For this researcher, this position comes with the bias of holding a positive perspective regarding study abroad programs in general, and in particular, the Japanese study abroad experience. To mitigate this bias, the coordinator did her best to set aside her experiences any time she would meet with the preservice teachers to collect. During the data collection process, she listened attentively to all the teachers and made sure she did not interject much about her own experience to prevent skewing or deviating from the conversations. The second author has been teaching courses related to comparative and international education including

topics related to study abroad. Thus, he is confined by Merriam's requirement of 
undertaking qualitative research.

At this point, it is important to note that as researchers and authors, we are inclined to support study abroad programs. At the same time, we are pride in being critical scholars who see the importance of examining study abroad programs in order to understand better their strengths and weaknesses as noted by the evidence presented in this study.

\section{Results}

The analysis of the preservice teacher journals and interview data yielded three themes: Learning About Different Languages, Cultures, and Norms; Thoughts about Education: Comparing and Contrasting Systems; and Influences on Teaching and Working with Diverse Students and Families: Shifting Culturally.

\section{Learning About Different Languages, Cultures, and Norms}

As previously stated, the study abroad program to Japan lasted over a period of four weeks. As part of the program, the preservice teachers stayed with Japanese families and were involved in cultural experiences such as attending festivals and tea ceremonies, adorning traditional kimonos, enrolling in a calligraphy course, sampling Japanese foods, and visiting temples. The preservice teachers also took Japanese language classes. The data analysis revealed that after being exposed to another culture and one that was significantly different from their own, the preservice teachers learned about a way of life that was different from their own. They learned cultures, communities, and families; how children are raised, how the dynamics and interactions occur within families and communities, how people treat each other, cultural norms and expectations. All the preservice teachers indicated that they did appreciate their experience and believed the study abroad trip was worthwhile. One of the preservice teachers called the experience "rewarding". He said:

Learning about other cultures in their own setting is completely eye opening and unlike anything I have ever experienced. I think the experience gave me a much broader outlook on life and a better appreciation for other cultures. Also, I became more understanding of other cultures. Now, I believe the world would be a much better place if there were more student exchange between countries.

Another preservice teacher noted: "I learned so much about the Japanese culture. Staying with a host family allowed me to see more of their culture which you wouldn't really see or fully understand unless you were with a Japanese family." Another preservice teacher noted, "I become aware of different cultures and learning styles of Japanese students as compared to U.S students. I think I have become a more globally competent person"

\section{Reflections on Education: Comparing and Contrasting Systems}


The preservice teachers had observational clinical hours at local elementary, middle, and high schools, and had the opportunity to interact with Japanese students in their classrooms. They got to see how the Japanese school system operated and how it differed from American schools. After this experience, the teachers all noted how they had had misconceptions about the education system in Japan. In fact, they were quite surprised at what they found. That is, while they found the school systems to be mostly different, they also noticed some similarities to the American system. One preservice teacher said:

What I expected Japan to be like was quite different. I had all these stereotypes. As teachers, we often stereotype where our students come from and what systems our international students and families have been through. This experience showed me that we can't listen to those stereotypes, instead we must find out information for ourselves and will find that people are not as different as we think.

In another preservice teacher's journal notes, she reported the following:

Before leaving the United States for Japan, I wasn't quite sure what to expect from the Japanese school systems. I knew that Japan typically scored higher on national tests and graduated more scientists than the United States, but I did not know how their education was set up.

In learning about Japanese education, I learned that after World War II, Japan adapted a school system that was outlined by American school systems. Japan has elementary school from grades one through six, and America has elementary school for grades one through five. Then, there is three years of junior high, the same as for America. Finally, Japan has 3 years of high school, and America has four years of high school.

The teachers could see first-hand how the two school systems (Japanese and American) compared. Most importantly, the teachers got to experience an educational system other than their own or one that they were not used to and observed the different ways in which students from other countries were taught as well as the culture from which they came. This experience broadened their knowledge regarding the field of education. They also got to learn about the educational system from whence some of their future students may or will come from.

\section{Influences on Teaching and Working with Diverse Students and Families: Shifting Culturally}

Living in Japan for a month with a host family allowed the preservice teachers to become fully engaged in the Japanese culture, and in turn, caused them to appreciate cultural differences. One preservice teacher said: "Coming from a cultural/racial minority myself, I already knew how important culturally responsive and relevant pedagogy is in diverse classrooms. This experience, however, has shown me that it is also very important to talk about cultural diversity, including the majority culture, even if your classroom isn't diverse." Another said: "It's important to talk about how we have different cultures, and 
we should all discuss how we need to work together even given these differences." Yet another preservice teacher said:

We must get to know our students, how and what makes them learn better. Importantly, we need to understand how certain experiences may affect learning. For instance, when I was the only white girl among a class of Japanese teachers and students, I had to deal with people staring and wondering about me. And this happened when I would go in the community as well. Based on this lived experience, I found myself thinking that we as teachers need to protect our students from that kind of feeling of being different. We need to teach our students to be understanding, but still curious about other cultures.

Another commented:

Having experienced a completely different culture then the one I am accustomed to, I am now much more aware of some of the changes students are encountering in a new environment. As a teacher, we must work to gather understanding of the different cultures and backgrounds that may be present in our classrooms. Ignoring cultures and only teaching one way can be very detrimental to children of ethnic backgrounds. I think as teachers we must continually be learning about new cultures and working to learn how their customs could be used in the classroom or how they typically learn.

When asked about how their experiences had influenced how they planned to incorporate culturally diverse lessons, teaching materials, and teaching styles into their classrooms, the teachers talked endlessly about the different strategies they were going to use. The following were shared as ideas for teaching:

1. Interweave cultural pieces into all the units taught in the class so as to make sure to include students' culture during everyday activities and lessons

2. Have students present things about their own culture

3. Have students interact and learn about each other's homelands and customs as this will be of great educational value

4. Bring up and discuss issues related to cultural and linguistic diversity during class time to help expose students to different ideas

5. Have students learn more about things that have happened in the past that has affected different cultures and therefore how they need to be more supportive

6. Share visuals, auditory and print texts related to different cultures in the classroom

7. Give students partners, work, and chances to be social with each other

8. Incorporate lessons about stereotyping and not allow stereotyping in my classroom

9. Findings ways to have students connect with each other and break down the cultural stereotypes by having students working together in groups on cultural activities 
10. Encourage recognizing and respecting differences between and among cultures.

\section{Discussion and Conclusions}

The purpose of this study was to explore the experiences of preservice teachers who participated in a short-term summer study abroad program and to find out and understand the ways by which the experience had influenced their plans for teaching and working with ethnically, culturally, and linguistically diverse students and families. The preservice teacher responses generally show an overall positive study abroad experience. The preservice teachers noted that the trip to Japan opened their mind and lives to a whole new world of thinking and ideas. Through this study abroad experience the teachers learned about a different culture, different customs and a different language. They learned about how a different country's school system works. And finally, through the international study abroad experience, the preservice teachers became more culturally aware, recognized diversity, and recognized the need to support and have other students understand their students who are ethnically, culturally, and linguistically different from them. The results were very similar to the study documented by Vatalaro, Szente, and Levin in 2015. Cushner (2007) and Quezada (2004) also noted a deeper understanding of cultural differences and cross-cultural sensitivity among study abroad participants.

Again, the results of the study are consistent with that of researchers who documented a variety of different learning outcomes associated with undergraduate education abroad-including intercultural competence (Deardorff, 2004, 2012, 2016), global competence (Morais \& Ogden, 2011), global perspectives and global citizenship (Bryant, 2006; Schattle, 2009; Carbrera, 2010; Ogden, 2010). For example, Bryant (2006) presented a persuasive argument that noted:

Perhaps we must, as some have suggested, detach the term "citizenship" from the discussion. The term historically has implied nationality but no single nation holds sway over a global citizen. Her activities are transnational and her commitment is to the human issues, not the nation state. Therefore, whether nationality is central to world-mindedness is questionable. One could defend national identity as the springboard for global participation since we tend to view the world through our own cultural lens. Still, the global citizen will have the moral equivalent of photogrey lenses that respond to changing environmental realities. (p. 1).

In a similar vein, Lagos (2001) presented a perspective that noted global citizens "as active political, social, environmental or economic agents in an interdependent world in which new institutional forms beyond nations are beginning to emerge" (p. 1). Tajes and Ortiz (2010) also suggested as an outcome of the study abroad program, a better understanding of diversity especially as it pertained to different languages and cultural practices. Indeed, students noted learning about and experiencing a different culture was very beneficial. 
One can say the preservice teacher experiences broadened the views they held. As a result of the study abroad experience, the preservice teachers indicated that they now empathized with students and families from diverse backgrounds (Savicki, 2010). The preservice teachers now felt they had a better understanding of how their culturally and linguistically minoritized students may feel being different in a learning space and said they planned to interact more and differently with people who were different from them. This finding is similar to what was noted by Fry, Paige, Jon, Dillow, and Nam (2009). The preservice teachers said they felt better trained to teach and work with students from different cultures (Devillar \& Jiang, 2012). Devillar and Jiang found that when given the opportunity to study abroad, educators develop culturally responsive instructional strategies and materials.

Other scholars noted that some of the important outcomes of study aboard programs also included self-awareness (Damschroder, 2016). Indeed, our study founded out that student-developed self-awareness about themselves and empathy towards others. In fact, Morais and Ogden (2011) informed us that study abroad participants developed an understanding of " having an open mind while actively seeking to understand others' cultural norms and expectations and leveraging this knowledge to interact, communicate, and work effectively outside one's environment" (p.4).

\section{Implications for Future Practice and Research}

It is important to note that for this study, we included students from the College of Education of one university located in the Midwestern Region of United States and used a qualitative design. Thus, the results are not generalizable to other colleges (e.g. students studying foreign languages) and universities across other regions in the United States. Another limitation of our study is that the majority of our sample are white female students as compared to males and underrepresented minoritized students who study abroad. This study is consistent with other literature about overrepresentation of white female students and underrepresentation of male and especially minority students (Booker, 2001; Brustein, 2007; Burkhart, Hexter, \& Thompson, 2001; Carter, 1991; Kasravi, 2009; Twombly, Salisbury, Tumanut, \& Klute, 2012). Thus, we caution not to draw generalization concerning these two demographics. Rather, results may be transferable to other settings and therefore still offer important insights regarding the influences of study abroad.

Given the results, preservice teachers need to be encouraged to study abroad to be exposed to different cultures and languages. Colleges of education should continue to establish and encourage their preservice teachers to participate in study abroad programs, and especially those that will occur in locations that are vastly different from what they, the preservice teachers, may be used to. Preservice teachers should be given the opportunity to learn different languages as well as interact in cultures that are different than their own. Instilling these traits in preservice teachers will better prepare them to teach and work with 
ethnically, culturally, and linguistically diverse students and their families.

Another implication for this study is that we recommend that colleges of education as well other colleges develop a robust funding mechanism that includes scholarships that will defray the cost of studying abroad, especially for underrepresented students. We urge higher education institutions to pay special heed to underrepresented and minoritized students and provide all students opportunities to study abroad. Indeed, in order to meet the goals articulated in Lincoln Commission (2006) and Generation Study Abroad (2015), we must diversify the study abroad population, so we can develop globally competent students who are successful in promoting and engaging cultural competency and global citizenship perspectives. The finding and results from this study can be used as way to internationalize campuses. Indeed, preservice students in our data noted that they enjoyed their experience and gained cultural competence skills that will enhance their preservice teaching experiences. Thus, we encourage that their experiences should be shared with the wider university community through workshops, as they can be useful for offices of International studies.

Future studies need to expand these findings with larger sample sizes of study abroad participants and who study in different international locations. In addition, research on other effects of study abroad programs on teacher education will be most appropriate. We also recommend that studies focusing on students from other colleges such as Social Sciences (e.g. Languages), Business, Technology, and Sciences should be conducted, and the findings compared and contrasted with those from the COE or Teacher education programs.

Institute of International Education (IIE) publishes reliable data about study abroad student participants, demographics, race, gender, etc. However, we know very little about the experiences of underrepresented students who study abroad, especially preservice teacher students from teacher education programs. We need to disaggregate the data to explore what obstacles underrepresented students encounter as they pursue study abroad opportunities and what made it possible for them to purse study abroad programs.

Deardorff and Jones (2012) argue that many universities have embraced intercultural competence as an important learning outcome for their graduates. Indeed, to become truly interculturally competent, a person must gain knowledge about multiple cultures, develop empathy for diverse perspectives, and be able to practice what Byram (as cited in Deardorff \& Jones, 2012) refers to as "critical cultural awareness" (p. 286). Furthermore, Deardorff and Jones inform us that although learning another language is a good start, language training must also be paired with cultural knowledge so that the new speaker can communicate in a culturally appropriate way. More research is needed to help understand how this process take place in many student abroad programs. Thus, empirical studies that help shed light on and increase our knowledge base this issue could take scholarly conversation on this subject forward in ways that can also guide practice, programming, and policy. 


\section{References}

Booker, R. W. (2001). Differences between applicants and non-applicants relevant to the decision to apply to study abroad. University of Missouri

Brustein, W. I. (2007). The global campus: Challenges and opportunities for higher education in North America. Journal of Studies in International Education, $11(3-4), 382$.

Bryant, D. (2006). The everyone, everywhere: Global dimensions of citizenship. In B. Holland and J. Meeropol (Eds.)., A more perfect vision: The future of campus engagement. Providence, RI: Campus Compact. Retrieved March 26, 2016 from http://compact.org/resource-posts/the-everyone-everywhere-global-dimensionsof-citizenship/4259/

Burkart, B., Hexter, H. \& Thompson, D. (2001). Why TRIO students need to study abroad. Washington, DC: Pell Institute.

Carter, H. M. (1991). Minority access to international education. In Black students and overseas programs: Broadening the base of participation (pp. 6-13). New York: Council on International Educational Exchange

Carbrera, L. (2010). The practice of global citizenship. Cambridge, UK: Cambridge University Press.

Creswell, J. W., \& Poth, C. N. (2013). Research design: Qualitative, quantitative, and mixed methods approaches (4th ed.). Thousand Oaks, CA: Sage Publications.

Cushner, K. (2007). The role of experience in the making of internationally-minded teachers. Teacher Education Quarterly, Winter, 27-39.

Damschroder , C. (2016), Learn by Doing: Faculty-Led Short-Term Study Abroad Designing and Developing Experiences, in Patrick Blessinger, Barbara Cozza (ed.) University Partnerships for International Development (Innovations in Higher Education Teaching and Learning, Volume 8) Emerald Group Publishing Limited, pp.229 - 246

Deardorff, D. K. (2016). Key theoretical frameworks guiding the scholar-practitioner in international education. In B. Streitwieser \& A. C. Ogden (Eds.), International higher education's scholar-practitioners: Bridging research and practice (246263). Oxford, U.K.: Symposium Books.

Deardorff, D., \& Jones, E. (2012). Intercultural competence: An emerging focus in international education. In D. Deardorff, H. de Wit, J. Heyl, \& T. Adams (Eds.), The SAGE handbook of international higher education. (pp. 283-303). Los Angeles, CA: Sage.

Deardorff, D.K. (2004, Spring) Internationalization: In search of intercultural competence. International Educator, 13-15. Retrieved from: http://www.nafsa.org//file/ /in search of intercultural.pdf

Deardorff, D. K. (2016). Key theoretical frameworks guiding the scholar-practitioner in international education. In B. Streitwieser \& A. C. Ogden (Eds.), International higher education's scholar-practitioners: Bridging research and practice (246263). Oxford, U.K.: Symposium Books.

DeVillar, R. A., \& Jiang, B. (2012). From student teaching abroad to teaching in the U.S. classroom: Effects of global experiences on local instructional practice. Teacher Education Quarterly, 39(3), 7-24.

Durbin, R. J. (2006). The Lincoln Commission and the future of study abroad. International Educator, 15, 4-6.

Fry, G. W., Paige, R. M., Jon, J., Dillow, J., \& Nam, K. (2009). Study abroad and its 
transformative power. Occasional Papers: On International Educational Exchange, 32.

Gay, G. (2010). Culturally responsive teaching: Theory, research, and practice. New York, NY: Teachers College Press.

Hoffa, W. W., \& DePaul, S. C. (2010). A history of U.S. study abroad: 1965-present. Carlisle, PA: The Forum on Education Abroad.

Institute of International Education (2015). Generation study abroad: About the initiative. Retrieved June 12, 2015 from http://www.iie.org/Programs/Generation-StudyAbroad/About

Ladson-Billings, G. (1994). The dreamkeepers. San Francisco: Jossey-Bass.

Ladson-Billings, G. (1995). But that's just good teaching. The case for culturally relevant pedagogy. Theory into Practice, 34(3), 159-165.

Merriam, S. B. (2009). Qualitative research: A guide to design and implementation. San Francisco: Jossey Bass.

Morris, C. (2017). Open Doors 2017 Executive Summary. Retrieved from https://www.iie.org/Why-IIE/Announcements/2017/11/2017-11-13-OpenDoors-2017-Executive-Summary

Mullens, J \& Cuper, P (2012) Fostering global citizenship through faculty-led International Programs. Charlotte, N.C.: Information Age Publishing.

Patton, M. Q. (2015). Qualitative research \& evaluation methods: Integrating theory and practice $\left(4^{\text {th }}\right.$ ed.). Thousand Oaks: CA, Sage.

Phillion, J., Malewski, E. L., Sharma, S., \& Wang, Y. (2009). Reimagining the curriculum: Future teachers and study abroad. Frontiers: The Interdisciplinary Journal of Study Abroad, 18, 323-339.

Quezada, R. (2004). Beyond educational tourism: Lessons learned while student teaching abroad. International Education Journal, 5(4), 458-465.

Quezada, R. L., \& Alfaro, C. (2007). Biliteracy teachers' self-reflections of their accounts while student teaching abroad: Speaking from "the other side." Teacher Education Quarterly, 34(1), 95-113.

Savicki, V. (2010). Implications of early sociocultural adaptation for study abroad students. Frontiers: The International Journal of Study Abroad, 19, 205-223.

Sleeter, C. E. (2001). Preparing teachers for culturally diverse schools research and the overwhelming presence of whiteness. Journal of Teacher Education, 52(2), 94106.

Tajes, M., \& Ortiz, J. (2010). Assessing study abroad programs: Application of the "SLEPT" framework through learning communities. The Journal of General Education, 59(1), 17-41.

Twombly, S. B., Salisbury, M. H., Tumanut, S. D., \& Klute, P. (2012). Study abroad in a new global century: Renewing the promise, refining the purpose. ASHE Higher Education Report, 38(4).

Vatalaro, A., Szente, J., \& Levin, J. (2015). Transformative learning of preservice teachers during study abroad in Reggio Emilia, Italy: A case study. Journal of the Scholarship of Teaching and Learning, 15(2), 42-55. 


\section{Author Bios}

Lydia Kyei-Blankson, $\mathrm{Ph} . \mathrm{D}$ is an Associate Professor in the department of Educational Administration and Foundations at Illinois State University. Her expertise and training is in research methods, applied statistics, and psychometrics. Her assignment at ISU includes teaching research methods and statistics graduate courses in the College of Education. Dr. Kyei-Blankson's research agenda focuses on the scholarship of teaching and learning and the implications of effective technology integration in teaching and learning.

Mohamed A. Nur-Awaleh, Ph.D. is an Associate Professor in the department of Educational Administration and Foundations at Illinois State University. His teaching and research expertise is in leadership, governance, comparative higher education and online education. His publications appeared in many journals in educational leadership, online education and comparative higher education. 